\title{
Pemantauan Kualitas Udara Kota Tegal (Studi Kasus : Kecamatan Tegal Selatan, Kecamatan Tegal Barat, Kecamatan Tegal Timur)
}

\author{
Andika Pradifan ${ }^{1}$, Widayat $^{1}$, dan Agus Suprihanto ${ }^{1}$ \\ 1Program Studi Pendidikan Profesi Insinyur, Universitas Diponegoro; e-mail: andika.pradifan@live.com
}

\begin{abstract}
ABSTRAK
Pengelolaan kualitas udara dan pengendalian pencemaran udara harus dilakukan untuk menjaga kelestarian dan keberlangsungan kehidupan. Pengelolaan dan pengendalian pencemaran udara dapat dilaksanakan dengan melakukan pemantauan kualitas udara. Hasil dari pemantauan kualitas udara ambien selanjutnya digunakan untuk perhitungan IKU. Indeks Kualitas Udara/IKU merupakan salah satu instrumen yang dapat digunakan untuk melakukan penilaian kualitas udara secara sederhana dengan menggunakan beberapa parameter terpilih. Indeks Standar Pencemar Udara/ISPU, Parameter yang digunakan untuk menentukan ISPU yaitu Sulfur Dioksida $\left(\mathrm{SO}_{2}\right)$, Nitrogen Dioksida $\left(\mathrm{NO}_{2}\right)$, Oksidan $\left(\mathrm{O}_{3}\right)$, Total Partikel (TSP), Karbon Monoksida (CO), Amoniak $\left(\mathrm{NH}_{3}\right)$, Hidrogen Sulfida $\left(\mathrm{H}_{2} \mathrm{~S}\right)$, Weather Station (Suhu Udara, Tekanan Udara, Kelembaban Udara), Arah dan Kecepatan Angin, GPS (Koordinat Lokasi), Tingkat Kebisingan, dan PM $_{10}$. Sedangkan untuk perhitungan Indeks Kualitas Udara menggunakan 2 parameter utama yaitu Nitrogen Oksida $\left(\mathrm{NO}_{\mathrm{x}}\right.$ ) dan Sulfur Oksida ( $\mathrm{SO}_{\mathrm{x}}$ ). Pengambilan sampel udara di Kota Tegal menggunakan alat High Volume Air Sampler (HVAS) dengan lama pengambilan selama 24 jam. Lokasi yang digunakan untuk pengambilan contoh kualitas udara ambien terletak di Jl. Dr. Cipto Mangunkusumo untuk pemantauan transportasi. Sedangkan untuk pemantauan kualitas udara dengan metode passive sampler memerlukan waktu selama 14 hari. Lokasi yang dipilih mewakili transportasi, kawasan permukiman, kawasan industri, kawasan perkantoran dan kawasan perdagangan. Pengambilan sampel kualitas udara ambien selama 24 jam digunakan untuk menghitung Nilai Indeks Standar Pencemar Udara (ISPU). Nilai ISPU pada lokasi pemantauan di Jl. Dr. Cipto Mangunkusumo (Terminal Kota Tegal) masing masing yaitu : $\mathrm{SO}_{2}$ sebesar 21,25, CO sebesar 10, $\mathrm{NO}_{2}$ sebesar 48, $\mathrm{O}_{3}$ sebesar 22,92 dan $\mathrm{PM}_{10}$ sebesar 40. Seluruh parameter termasuk dalam rentang 0 - 50 dengan kategori baik.
\end{abstract}

Kata kunci: Pemantauan kualitas udara, Metode passive sampler, Ambient 24 jam, Kota Tegal, Indeks standar pencemar udara

\begin{abstract}
Air quality management and air pollution control must be carried out to maintain their function and maintain the preservation and sustainability of life. Air pollution control and management can be carried out by monitoring air quality. The results from ambient air quality monitoring can be used for KPI calculations. The Air Quality Index / IKU is an instrument that can be used to perform a simple air quality assessment using selected parameters. Air Pollutant Standard Index / ISPU, the parameters used to determine the ISPU are Sulfur Dioxide $\left(\mathrm{SO}_{2}\right)$, Nitrogen Dioxide $\left(\mathrm{NO}_{2}\right)$, Oxidants $\left(\mathrm{O}_{3}\right)$, Total Particles (TSP), Carbon Monoxide (CO), Ammonia $\left(\mathrm{NH}_{3}\right)$, Hydrogen Sulfide $\left(\mathrm{H}_{2} \mathrm{~S}\right)$, Weather Station (Air Temperature, Air Pressure, Air Humidity), Wind Direction and Speed, GPS (Location Coordinates), Noise Level, and $\mathrm{PM}_{10}$. Meanwhile, the IKU calculation uses 2 main parameters, namely Nitrogen Oxide $\left(\mathrm{NO}_{\mathrm{x}}\right)$ and Sulfur Oxide $\left(\mathrm{SO}_{\mathrm{x}}\right)$. Taking air samples in Tegal City uses a High Volume Air Sampler (HVAS) tool with a 24 hour collection time. The location used for sampling the ambient air quality is located on Jl. Dr. Cipto Mangunkusumo for transportation monitoring. While air quality monitoring using the passive sampler method takes 14 days. The selected locations represent transportation, residential areas, industrial areas, offices areas and trade areas. 24-hour ambient air quality sampling is used to calculate the Air Pollutant Standard Index (ISPU) value. ISPU value at the monitoring location on Jl. Dr. Cipto Mangunkusumo (Tegal City Terminal), respectively: $\mathrm{SO}_{2}$ of 21,25, $\mathrm{CO}$ of 10, $\mathrm{NO}_{2}$ of 48, $\mathrm{O}_{3}$ of 22,92 and $\mathrm{PM}_{10}$ of 40 . All parameters fall into the range 0 - 50 with a good category.
\end{abstract}

Keywords: Air Quality Monitoring, Passive sampler Method, 24 Hours Ambient, Tegal City, Air Pollutant Standard Index

Citation: Pradifan, A., Widayat, dan Suprihanto, A. (2021). Pemantauan Kualitas Udara Kota Tegal (Studi Kasus : Kecamatan Tegal Selatan, Kecamatan Tegal Barat, Kecamatan Tegal Timur). Jurnal Ilmu Lingkungan, 19(1), 73-82, doi:10.14710/jil.19.1.73-82

\section{Pendahuluan}

Pencemaran udara dapat disebabkan oleh kebakaran, gunung meletus, gas alam beracun, dan lain-lain yang mengandung senyawa berbahaya, salah satunya adalah gas karbon monoksida (Weebly, di akses 2020). Pemantauan kualitas udara ambien dapat dilakukan dengan metode otomatis maupun manual. Terdapat dua jenis pada metode otomatis, yaitu fixed station (permanen) dan mobile station. Sedangkan metode manual terdiri dari manual aktif dan manual passive. Semua metode pemantauan memiliki kelebihan dan kekurangan 
Pradifan, A., Widayat, dan Suprihanto, A. (2021). Pemantauan Kualitas Udara Kota Tegal (Studi Kasus : Kecamatan Tegal Selatan, Kecamatan Tegal Barat, Kecamatan Tegal Timur). Jurnal Ilmu Lingkungan, 19(1), 73-82, doi:10.14710/jil.19.1.73-82

masing-masing, sehingga penggunaan metode pemantauan perlu disesuaikan dengan tujuan dari pemantauan udara ambien itu sendiri (Akmal, 2009).

Hasil dari pemantauan kualitas udara ambien dapat digunakan untuk perhitungan Indeks Kualitas Udara. Indeks Kualitas Udara/IKU merupakan salah satu instrumen yang dapat digunakan untuk melakukan penilaian kualitas udara secara sederhana dengan menggunakan beberapa parameter terpilih. Sesuai dengan Keputusan Menteri Lingkungan Hidup Nomor : KEP 45/MENLH/10/1997 dan KEP107/KABAPEDAL/11/1997 tentang Indeks Standar Pencemar Udara/ISPU, parameter yang digunakan untuk menentukan ISPU yaitu Sulfur Dioksida $\left(\mathrm{SO}_{2}\right)$, Nitrogen Dioksida $\left(\mathrm{NO}_{2}\right)$, Ozon $\left(\mathrm{O}_{3}\right)$, Total Partikel (TSP), Karbon Monoksida (CO), Amoniak $\left(\mathrm{NH}_{3}\right)$, Hidrogen Sulfida $\left(\mathrm{H}_{2} \mathrm{~S}\right)$, Weather Station (Suhu Udara, Tekanan Udara, Kelembaban Udara), Arah dan Kecepatan Angin, GPS (Koordinat Lokasi), Tingkat Kebisingan, dan $\mathrm{PM}_{10}$. Sedangkan untuk perhitungan IKU menggunakan 2 parameter utama yaitu Nitrogen Oksida $\left(\mathrm{NO}_{\mathrm{x}}\right)$ dan Sulfur Oksida $\left(\mathrm{SO}_{\mathrm{x}}\right)$. Hasil dari perhitungan IKU dapat digunakan untuk mengetahui kondisi pencemaran udara di suatu wilayah sekaligus untuk mengevaluasi keberhasilan upaya pengelolaan dan pengendalian pencemaran udara (Badan Meteorologi Klimatologi dan Geofisika, 2012).

Berdasarkan data badan pusat statistik (BPS) Kota Tegal pada tahun 2019, jumlah peduduk Kota Tegal sebanyak 249.905 jiwa. Padatnya penduduk berbanding lurus dengan kebutuhan transportasi masyarakat guna mendukung aktivitas masyarakat sehari-hari. Kebutuhan transportasi pada masyarakat selanjutnya dapat berdampak pada perubahan kualitas udara akibat adanya aktivitas transportasi yang tinggi.

Selain itu, pertumbuhan ekonomi kota menyebabkan peningkatan kegiatan industri yang turut serta berkontribusi pada penurunan kualitas udara. Penurunan kualitas udara dapat juga bersumber dari kegiatan pertanian, pengelolaan sampah, debu, penggunaan energi dalam rumah tangga, serta kegiatan pembangkit energi.

Berdasarkan data Dinas Lingkungan Hidup Kota Tegal, terdapat penurunan nilai pada Indeks Pencemaran Udara Kota Tegal pada rentang tahun 2015 - 2017. Pada Tahun 2015, indeks pencemaran yang tercatat sebesar 27,3 dan pada Tahun 2017, indeks pencemaran berkurang menjadi 25,4. Namun, berdasarkan data Dinas Kesehatan Kota Tegal Tahun 2018, jumlah penderita ISPA di Kota Tegal kian meningkat pada rentang tahun 2015 - 2017. Pada Tahun 2015, jumlah penderita ISPA sebanyak 16.343 jiwa dan terus meningkat sampai dengan 30.869 jiwa pada Tahun 2017.

Berdasarkan data tersebut, penurunan kualitas udara tidak berbanding lurus dengan banyaknya masyarakat yang terkena penyakit ISPA. Maka dari itu, diperlukan upaya untuk terus melakukan pemantauan dan pengawasan terhadap kualitas udara dengan melakukan monitoring pada beberapa titik di Kota Tegal. Hasil monitoring dapat menunjukkan ada 74 atau tidaknya penurunan kualitas udara. Hasil tersebut selanjutnya dapat digunakan sebagai evaluasi dan tindak lanjut pemerintah dalam mengatasi masalah penurunan kualitas udara Kota Tegal. Pelaksanaan kegiatan "Koordinasi Penilaian Langit Biru", terdiri dari beberapa pekerjaan, salah satunya yaitu Pemantauan kualitas udara ambien. Pekerjaan ini dilakukan untuk memantau kualitas udara ambien di beberapa lokasi kegiatan masyarakat yang diduga telah mengalami penurunan kualitas udara.

\section{Metode Penelitian}

\subsection{Persiapan Data Dasar}

1. Persiapan

Tahap persiapan meliputi pemahaman KAK, penyusunan metode dan rencana kerja, mobilisasi tim penyusun.

2. Data Dasar

Data dasar yang digunakan dalam pemantauan kualitas udara ambien Kota Tegal yaitu:

a. Data lokasi sampling dengan keterwakilan wilayah pemukiman, transportasi, dan perekonomian.

b. Data parameter dasar yang digunakan.

\subsection{Pengumpulan Data}

Tahap pengumpulan data dilakukan dengan menggunakan data primer yang berupa kegiatan pengambilan contoh 1 (satu) titik sampling kualitas udara ambien selama 24 jam dan pada 5 titik menggunakan metode passive sampler. Lokasi pengambilan contoh mewakili pemantauan untuk transportasi. Sedangkan 5 titik pemantauan dengan menggunakan metode passive sampler mewakili pemantauan untuk transportasi, kawasan pemukiman, kawasan industri, perkantoran, dan kawasan perdagangan. Lokasi titik sampling dipilih karena merupakan pusat kegiatan masyarakat yang berpotensi menghasilkan pencemaran udara baik dari sumber bergerak maupun sumber tidak bergerak.

\subsection{Alat dan Bahan yang Diperlukan}

Metode sampling dengan menggunakan alat :

a. Air sampler Impinger, berfungsi untuk analisis dan evaluasi kadar kontaminan udara seperti gas $\mathrm{SO}_{2}, \mathrm{H}_{2} \mathrm{~S}, \mathrm{NH}_{3}, \mathrm{NO}_{\mathrm{x}}, \mathrm{O}_{\mathrm{x}}$, dsb. Dalam impinger terdapat pompa vakum, tabung impinger, flow meter serta independent exhaust mini fan.

b. Sound Level Meter, menggunakan merk Benetech dengan tipe GM1356. Merupakan alat untuk mengukur tingkat kebisingan dalam satuan desibel (dB).

c. Anemometer, menggunakan merk Lutron dengan tipe LM-8100. Alat tersebut berfungsi untuk membaca kecepatan angin, kelembaban ruang, dan suhu.

d. High Volume Air Sampler (HVAS), merupakan alat pengambil sampel partikulat di udara ambien $\left(\mathrm{PM}_{10}\right)$.

e. Global Positioning System (GPS), dengan merk Garmin Tipe GPSmap 60CSx. 


\subsection{Penentuan Titik Lokasi}

Penentuan lokasi pemantauan udara ambien dilaksanakan sesuai SNI 19-7119.6-2005 Udara Ambien- Bagian 6 : Penentuan Lokasi Pengambilan Contoh Uji Pemantauan Kualitas Udara Ambien dan SNI 19-7119.9-2005 Udara Ambien - Bagian 9.

\subsection{Parameter yang Dianalisis}

Kualitas Udara Ambien : Sulphur Dioksida $\left(\mathrm{SO}_{2}\right)$; Nitrogen Dioksida $\left(\mathrm{NO}_{2}\right)$; Ozon $\left(\mathrm{O}_{3}\right)$; Total Partikel (TSP); Carbon Monooksida (CO); Amoniak ( $\mathrm{NH}_{3}$ ); Hidrogen Sulfida $\left(\mathrm{H}_{2} \mathrm{~S}\right)$; Weather Station (Suhu udara, tekanan udara, kelembaban udara) Arah dan kecepatan angin GPS (Global Positioning System), Koordinat lokasi; Tingkat kebisingan; $\mathrm{PM}_{10}$ (24 jam); Kualitas Udara dengan Passive sampler; Sulfur Oksida $\left(\mathrm{SO}_{\mathrm{x}}\right)$; Nitrogen Oksida $\left(\mathrm{NO}_{\mathrm{x}}\right)$.

\subsection{Metode ISPU}

Tahapan ini meliputi analisis data dan pembahasan. Data tersebut merupakan hasil penelitian pada lapangan dan pemantauan yang telah dilakukan. Data dianalisis dengan menggunakan perhitungan dan tabel acuan dalam perhitungan ISPU.

\section{Hasil dan Pembahasan}

Pengambilan contoh kualitas udara ambien dilakukan pada 1 (satu) titik sampling kualitas udara ambien selama 24 jam dan di 5 (lima) titik sampling menggunakan metode passive sampler yang tersebar di Kota Tegal. Lokasi pengambilan contoh kualitas udara diambil untuk mewakili beberapa kawasan di Kota Tegal, antara lain kawasan permukiman, kawasan industri, perkantoran, transportasi dan perdagangan. Lokasi tersebut adalah sebagai berikut:

Tabel 1. Lokasi Pengambilan Uji Udara Ambien

\begin{tabular}{|c|c|c|c|}
\hline No & Lokasi Sampling & Koordinat & Metode Sampling \\
\hline 1. & Transportasi (Jl. Dr. Cipto Mangunkusumo) & $\begin{array}{l}\text { LS : } 6^{\circ} 52^{\prime} 29.40^{\prime \prime} \\
\text { BT : } 109^{\circ} 6^{\prime} 21.93^{\prime \prime}\end{array}$ & $\begin{array}{l}\text { Pengambilan contoh kualitas udara } \\
\text { ambien ( } 24 \text { jam) }\end{array}$ \\
\hline 2. & Transportasi (Jl. Mataram) & $\begin{array}{l}\text { LS : 6०52'16.99" } \\
\text { BT : } 109^{\circ} 6^{\prime} 29.22^{\prime \prime}\end{array}$ & Passive sampler \\
\hline 3. & Permukiman (Kecamatan Tegal Selatan) & $\begin{array}{l}\mathrm{LS}: 6^{\circ} 53^{\prime} 43.11^{\prime \prime} \\
\mathrm{BT}: 109^{\circ} 6^{\prime} 59.11^{\prime \prime}\end{array}$ & Passive sampler \\
\hline 4. & Industri (Jl. Mataram) & $\begin{array}{l}\text { LS : } 6^{\circ} 51^{\prime} 27.38^{\prime \prime} \\
\text { BT : } 109^{\circ} 6^{\prime} 29.32^{\prime \prime}\end{array}$ & Passive sampler \\
\hline 5. & Perkantoran (Balaikota Tegal) & $\begin{array}{l}\text { LS : } 6^{\circ} 52^{\prime} 10.60^{\prime \prime} \\
\text { BT : } 109^{\circ} 8^{\prime} 15.28^{\prime \prime}\end{array}$ & Passive sampler \\
\hline 6. & Perdagangan (Jl. Ahmad Yani/Pasar Pagi) & $\begin{array}{l}\text { LS : } 6^{\circ} 51^{\prime} 56.00^{\prime \prime} \\
\text { BT : } 109^{\circ} 8^{\prime} 12.23^{\prime \prime}\end{array}$ & Passive sampler \\
\hline
\end{tabular}

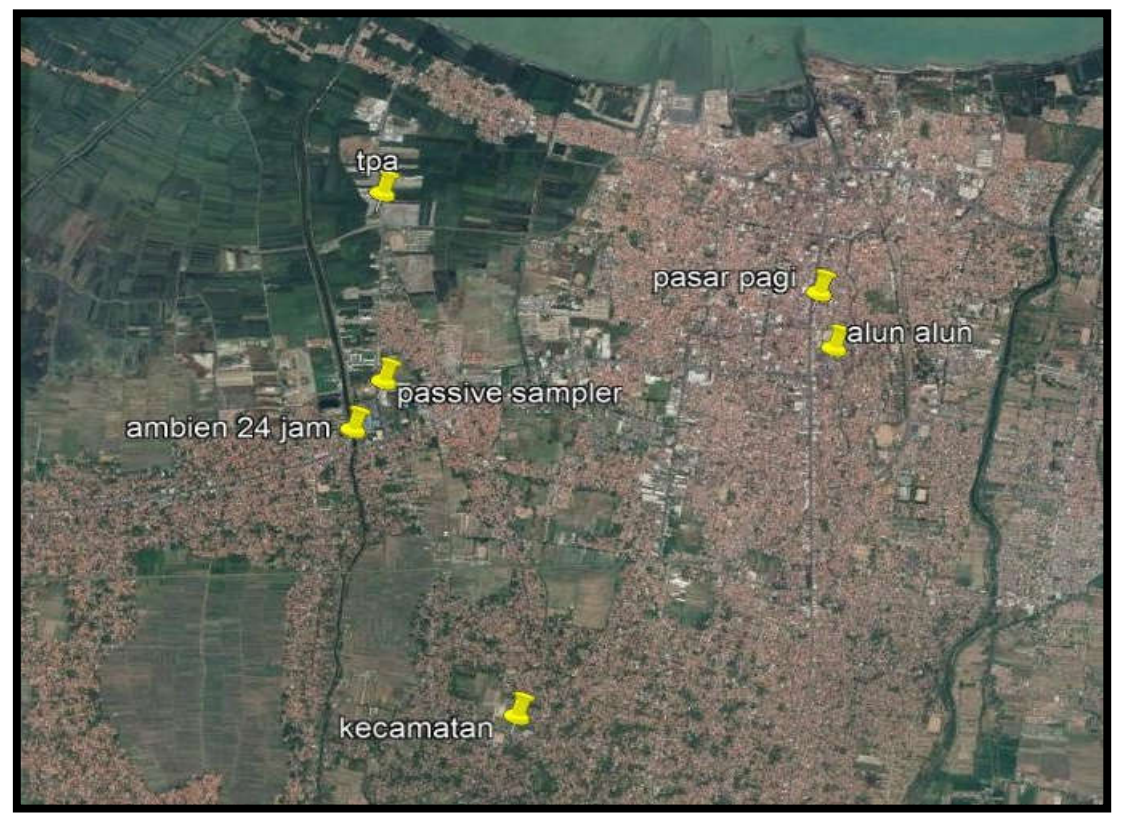

Gambar 1. Peta Lokasi Titik Sampling

Keterangan :

Transportasi (Jl. Dr. Cipto Mangunkusumo) : Ambien 24 jam

Transportasi (Jl. Mataram) : Passive sampler

Permukiman (Kecamatan Tegal Selatan) : Kecamatan

Industri (Jl. Mataram) : TPA

Perkantoran (Balaikota Tegal) : Alun-Alun

Perdagangan (Jl. Ahmad Yani/Pasar Pagi) : Pasar pagi 
Hasil pemantauan kualitas udara ambien dan kualitas udara di 5 titik sampling menggunakan metode passive sampler terdapat dalam tabel berikut ini :

Tabel 2. Hasil Pemantauan di Jl. Dr. Cipto Mangunkusumo

\begin{tabular}{|c|c|c|c|c|}
\hline No. & Parameter & SAT & Hasil Pengujian & Baku Mutu SK Gub. Jateng No. 8 Th 2001 \\
\hline 1. & Sulfur dioksida $\left(\mathrm{SO}_{2}\right)$ & $\mu \mathrm{g} / \mathrm{Nm}^{3}$ & $<34$ & 632 \\
\hline 2. & Nitrogen Dioksida $\left(\mathrm{NO}_{2}\right)$ & $\mu \mathrm{g} / \mathrm{Nm}^{3}$ & 48 & 316 \\
\hline 3. & Ozon $\left(\mathrm{O}_{3}\right)$ & $\mu \mathrm{g} / \mathrm{Nm}^{3}$ & 55 & 235 \\
\hline 4. & Carbon Monoksida (CO) & $\mu \mathrm{g} / \mathrm{Nm}^{3}$ & 1 & 15000 \\
\hline 5. & Debu, TSP & $\mu \mathrm{g} / \mathrm{Nm}^{3}$ & 131 & 230 \\
\hline 6. & Pertikel < $10 \mu \mathrm{m}\left(\mathrm{PM}_{10}\right)$ & $\mu \mathrm{g} / \mathrm{Nm}^{3}$ & 40 & 65 \\
\hline 7. & Sulfida & Ppm & 0,04 & 0,02 \\
\hline 8. & Amoniak $\left(\mathrm{NH}_{3}\right)$ & Ppm & 0,03 & 2 \\
\hline 9. & Tingkat Kebisingan & $\mathrm{dBA}$ & 71 & 70 \\
\hline \multirow[t]{10}{*}{10.} & Parameter Lapangan : & & & \\
\hline & Temperatur & $: 39,0$ & & \\
\hline & Kelembapan (\%) & $: 44,1$ & & \\
\hline & Cuaca & : Cerah & & \\
\hline & Tekanan Udara (mmHg) & $: 757,6$ & & \\
\hline & Flow Rate Impinger (L/Menit) & $: 0,2 ; 0,4$ & & \\
\hline & Flow Rate HVS ( $\mathrm{m}^{3} /$ Menit) & $: 1,2$ & & \\
\hline & Kecepatan angin (m/detik) & $: 0,0-0,2$ & & \\
\hline & Arah Angin & : Utara k & & \\
\hline & Posisi Geografis & $: S 06^{\circ} 52$ & 9०6'21,93" & \\
\hline
\end{tabular}

\subsection{Kawasan Transportasi Jl. Dr. Cipto Mangunkusumo}

Koordinat lokasi pada titik sampling di Jl. Dr. Cipto Mangunkusumo yaitu : LS 06 52' 29,40" BT $109^{\circ} 6^{\prime} 21,93$ ". Titik sampling di Jalan Dr. Cipto Mangunkumuso terletak di depan pintu masuk Terminal Kota Tegal. Lokasi dipilih karena merupakan pusat keramaian masyarakat seperti adanya kepadatan lalu lintas kendaraan bermotor yang memungkinkan terjadinya penurunan kualitas udara.

Dari hasil pemantauan diperoleh data kualitas udara ambien sebagai berikut : $\mathrm{SO}_{2}=<34 \mu \mathrm{g} / \mathrm{Nm}^{3}$, $\mathrm{NO}_{2}=48 \mu \mathrm{g} / \mathrm{Nm}^{3}, \mathrm{O}_{3}=55 \mu \mathrm{g} / \mathrm{Nm}^{3}, \mathrm{CO}=1 \mu \mathrm{g} / \mathrm{Nm}^{3}$, $\mathrm{TSP}=131 \mu \mathrm{g} / \mathrm{Nm} 3$, partikel $<10 \mu \mathrm{m}(\mathrm{PM} 10)=40$ $\mu \mathrm{g} / \mathrm{Nm}^{3}$, Sulfida 0,04 ppm, Amoniak $\left(\mathrm{NH}_{3}\right)$ 0,03 ppm dan rata rata kebisingan $=71 \mathrm{dBA}$.

Berdasarkan hasil pengukuran selama 24 jam, lokasi titik sampling di depan pintu masuk Terminal Kota Tegal memiliki kualitas udara ambien yang masih berada di bawah baku mutu. Berdasarkan penelitian Fauziah dkk, konsentrasi debu ( $\left.\mathrm{PM}_{10}\right)$ dapat dipengaruhi oleh suhu dan kelembaban. Nilai parameter suhu dan kecepatan angin yang positif berarti semakin tinggi suhu udara dan hembusan angin yang lebih cepat akan menyebabkan penyebaran partikel debu di udara semakin tinggi (Aisyiah, 2014).

Untuk parameter sulfida berada di atas baku mutu berdasarkan SK Gub Jateng nomor 8 tahun 2001, sebesar 0,02 ppm. Kebisingan berada diatas baku mutu menurut SK Men LH nomor 48 tahun 1996 sebesar 70 dBA. Nilai kebisingan yang cukup tinggi disebabkan salah satunya oleh padatmya aktivitas kendaraan yang keluar-masuk terminal Kota Tegal. Selain itu, nilai partikulat yang terukur cukup tinggi, namun masih berada di bawah baku mutu sesuai SK Gub Jateng nomor 8 tahun 2001. Hasil pemantauan transportasi dengan metode passive sampler terdapat dalam tabel berikut ini :

Tabel 3. Hasil Pemantauan Transportasi di Jl. Mataram (Passive Sampler)

\begin{tabular}{|c|c|c|c|c|}
\hline No & Parameter & Satuan & Hasil & Baku Mutu SK Gub. Jateng No. 8 Th 2001 \\
\hline 1. & Sulfur Dioksida $\left(\mathrm{SO}_{2}\right)$ & $\mu \mathrm{g} / \mathrm{m}^{3}$ & 10 & 632 \\
\hline \multirow[t]{3}{*}{2.} & Nitrogen Dioksida $\left(\mathrm{NO}_{2}\right)$ & $\mu \mathrm{g} / \mathrm{m}^{3}$ & 7 & 316 \\
\hline & Titik lokasi & : Terminal & & \\
\hline & Koordinat & : S $06^{\circ} 52^{\prime} 16,99$ & & \\
\hline
\end{tabular}

\subsection{Kawasan Transportasi Jl. Mataram}

Pengukuran kualitas udara ambien dengan menggunakan metode Passive sampler pada kawasan transportasi, dilaksanakan pada Terminal Kota Tegal dengan koordinat lokasi sampling : LS 06 52'16,99" BT 109० 06'29,22". Lokasi dipilih karena merupakan pusat kegiatan masyarakat terhadap aktivitas transportasi, yaitu pusat pemberhentian angkutan umum serta memiliki akses yang mudah untuk keluar masuk kendaraan bermotor lainnya. Semakin banyaknya volume lalu lintas yang ada di terminal, menyebaban peningkatan pencemaran udara. Proses pembakaran kendaraan dengan bahan bakar solar akan menghsilkan emisi leih tinggi daripada kendaraan berbahan bakar bensin (Fuziah dkk, 2017). Berdasarkan hasil pemantauan diperoleh data kualitas udara ambien di terminal Kota Tegal dengan metode passive sampler sebagai berikut : $\mathrm{SO}_{2}=10$ $\mu \mathrm{g} / \mathrm{Nm}^{3}, \mathrm{NO}_{2}=7 \mu \mathrm{g} / \mathrm{Nm}^{3}$. Dari pengukuran tersebut, dapat disimpulkan bahwa kualitas udara ambien pada terminal masih berada di bawah baku mutu sesuai SK Gub Jateng nomor 8 tahun 2001. Hasil pemantauan kawasan permukiman dengan metode passive sampler terdapat dalam tabel berikut ini. 
Tabel 4. Hasil Pemantauan di Permukiman Kecamatan Tegal Selatan (Passive Sampler)

\begin{tabular}{cllcc}
\hline \hline No & \multicolumn{1}{c}{ Parameter } & Satuan & Hasil & Baku Mutu SK Gub. Jateng No. 8 Th 2001 \\
\hline 1. & Sulfur Dioksida $\left(\mathrm{SO}_{2}\right)$ & $\mu \mathrm{g} / \mathrm{m}^{3}$ & 6 & 632 \\
2. & Nitrogen Dioksida $\left(\mathrm{NO}_{2}\right)$ & $\mu \mathrm{g} / \mathrm{m}^{3}$ & 4 & 316 \\
& Titik lokasi & $:$ Kecamatan Tegal Selatan & \\
& Koordinat & $: \mathrm{S} 06^{\circ}$ 53'43,11" E 109 06' 59,11" & \\
\hline
\end{tabular}

\subsection{Kawasan Permukiman Kecamatan Tegal Selatan}

Pengukuran kualitas udara ambien pada kawasan permukiman terletak di Kecamatan Tegal Selatan dengan koordinat lokasi : LS 06 53'43,11" BT 10906' 59,11". Lokasi berada di depan kantor Kecamatan Tegal Selatan. Lokasi dipilih karena berdekatan dengan permukiman warga. Berdasarkan hasil pemantauan, diperoleh data kualitas udara ambien di
Kecamatan Tegal Selatan dengan metode passive sampler sebagai berikut: $\mathrm{SO}_{2}=6 \mu \mathrm{g} / \mathrm{Nm}^{3}, \mathrm{NO}_{2}=4$ $\mu \mathrm{g} / \mathrm{Nm}^{3}$. Dari hasil pengukuran tersebut, kualitas udara ambien untuk kawasan permukiman di Kecamatan Tegal Selatan masih berada di bawah baku mutu sesuai SK Gub Jateng nomor 8 tahun 2001. Hasil pemantauan pada Kawasan Industri dengan metode passive sampler terdapat dalam tabel berikut ini :

Tabel 5. Hasil Pemantauan di Kawasan Industri Jl. Mataram (Passive Sampler)

\begin{tabular}{|c|c|c|c|c|}
\hline No & Parameter & Satuan & Hasil & Baku Mutu SK Gub. Jateng No. 8 Th 2001 \\
\hline 1. & Sulfur Dioksida $\left(\mathrm{SO}_{2}\right)$ & $\mu \mathrm{g} / \mathrm{m}^{3}$ & 8 & 632 \\
\hline \multirow[t]{3}{*}{2.} & Nitrogen Dioksida $\left(\mathrm{NO}_{2}\right)$ & $\mu \mathrm{g} / \mathrm{m}^{3}$ & 5 & 316 \\
\hline & Titik lokasi & : Jl. Mataram & & \\
\hline & Koordinat & $S 06^{\circ} 51^{\prime} 27,3$ & $06^{\prime} 29,32$ " & \\
\hline
\end{tabular}

\subsection{Kawasan Industri Jl. Mataram}

Lokasi yang menjadi perwakilan untuk pengukuran kualitas udara pada kawasan industri terletak di Jl. Mataram dengan koordinat lokasi : LS 06 51'27,38” BT 109 06' 29,32". Lokasi terpilih berdekatan dengan Tempat Pemrosesan Akhir (TPA) Murareja. Lokasi dipilih karena berada di dalam kawasan industri. Dari hasil pemantauan diperoleh data kualitas udara ambien untuk Kawasan Industri di
Jl. Mataram dengan metode passive sampler yaitu : $\mathrm{SO}_{2}=8 \mu \mathrm{g} / \mathrm{Nm}^{3}, \mathrm{NO}_{2}=5 \mu \mathrm{g} / \mathrm{Nm}^{3}$. Dari hasil pengukuran tersebut terlihat bahwa di TPA Muarareja memiliki kualitas udara ambien yang masih berada di bawah baku mutu sesuai SK Gub Jateng nomor 8 tahun 2001. Hasil pemantauan pada Kawasan Perkantoran dengan metode passive sampler terdapat dalam tabel berikut ini.

Tabel 6. Hasil Pemantauan di Kawasan Perkantoran BalaikotaTegal (Passive Sampler)

\begin{tabular}{|c|c|c|c|c|}
\hline No & Parameter & Satuan & Hasil & Baku Mutu SK Gub. Jateng No. 8 Th 2001 \\
\hline 1. & Sulfur Dioksida $\left(\mathrm{SO}_{2}\right)$ & $\mu \mathrm{g} / \mathrm{m}^{3}$ & 5 & 632 \\
\hline \multirow[t]{3}{*}{2.} & Nitrogen Dioksida $\left(\mathrm{NO}_{2}\right)$ & $\mu \mathrm{g} / \mathrm{m}^{3}$ & 4 & 316 \\
\hline & Titik lokasi & : Balaikota Te & & \\
\hline & Koordinat & : S $06^{\circ} 52^{\prime} 10$ & $08^{\prime} 15,28^{\prime \prime}$ & \\
\hline
\end{tabular}

\subsection{Kawasan Perkantoran Balaikota Tegal}

Titik sampling udara ambien untuk kawasan perkantoran yaitu Balaikota Tegal. Lokasi ini terletak di Jalan Ki Gede Sebayu. Di lokasi ini terletak Kantor Walikota Tegal dan merupakan Kawasan Car Free Day (CFD) yang dilaksanakan pada hari minggu pada jam $5.30 \mathrm{~s} / \mathrm{d} 8.30$ WIB. Balaikota Tegal merupakan pusat perkantoran di Kota Tegal yang menjadi salah satu pusat keramaian kota. Lokasi Balai Kota Tegal berdekatan dengan alun-alun kota. Koordinat lokasi sampling adalah LS $06^{\circ} 52^{\prime} 10,60^{\prime \prime}$ BT 109 08' 15,28”.
Dari titik pemantauan diperoleh data kualitas udara ambien sebagai berikut: $\mathrm{SO}_{2}=5 \mu \mathrm{g} / \mathrm{Nm}^{3}, \mathrm{NO}_{2}=4$ $\mu \mathrm{g} / \mathrm{Nm}^{3}$. Dari pengukuran tersebut terlihat bahwa alun-alun Kota Tegal dalam kondisi yang tidak terlalu ramai, sehingga baik nilai uji gas-gas menunjukkan kondisi yang baik, dan berada di bawah baku mutu sesuai SK Gub Jateng nomor 8 tahun 2001. Hasil pemantauan pada Kawasan Perdagangan dengan metode passive sampler terdapat dalam tabel berikut ini.

Tabel 7. Hasil Pemantauan di Kawasan Perdagangan Pasar Pagi (Passive Sampler)

\begin{tabular}{cllcc}
\hline \hline No & \multicolumn{1}{c}{ Parameter } & Satuan & Hasil & Baku Mutu SK Gub. JatengNo. 8 Th 2001 \\
\hline 1. & Sulfur Dioksida $\left(\mathrm{SO}_{2}\right)$ & $\mu \mathrm{g} / \mathrm{m}^{3}$ & 7 & 632 \\
2. & Nitrogen Dioksida $\left(\mathrm{NO}_{2}\right)$ & $\mu \mathrm{g} / \mathrm{m}^{3}$ & 5 & 316 \\
& Titik lokasi & : Pasar Pagi (Jalan Ahmad Yani) & \\
& Koordinat & $: \mathrm{S} 06^{\circ}$ 51' 56,00” E 109 08' 12,23” & \\
\hline
\end{tabular}

\subsection{Kawasan Perdagangan Pasar Pagi}

Pasar Pagi Kota Tegal dipilih menjadi titik sampling pengukuran kualitas udara untuk kawasan perdagangan. Pasar pagi merupakan pusat perdagangan dan ekonomi masyarakat yang menjadikan pasar ini cukup ramai. Koordinat lokasi yaitu : LS 06 51' 56,00" BT 109 08' 12,23". Dari hasil pemantauan diperoleh data kualitas udara ambien di Pasar Pagi dengan metode passive sampler sebagai berikut: $\mathrm{SO}_{2}=7 \mu \mathrm{g} / \mathrm{Nm}^{3}, \mathrm{NO}_{2}=5 \mu \mathrm{g} / \mathrm{Nm}^{3}$. Nilai pada 
parameter N02, cukup rendah dibandingkan dengan hasil penelitian Nurmaningsih (2018) yang melakukan pemantauan kualitas udara di Kawasan Pertokoan Coyudan Surakarta. Dengan hasil $\mathrm{NO}_{2}$ tertinggi terdapat pada pukul $12.30-13.30$ dengan nilai 1,258 $\mathrm{ppm}$ atau $23,65 \mu \mathrm{g} / \mathrm{Nm}^{3}$. Dari hasil pengukuran tersebut terlihat bahwa kualitas udara di Pasar Pagi masih berada di bawah baku mutu sesuai SK Gub Jateng nomor 8 tahun 2001.

Berikut rekapitulasi hasil dari pemantauan kualitas udara ambien dengan passive sampler.

Tabel 8. Rekapitulasi Hasil Pemantauan Kualitas Udara Ambien dengan Passive sampler

\begin{tabular}{lcc}
\hline \hline Titik Pantau & $\mathrm{SO}_{2}\left(\mu \mathrm{g} / \mathrm{Nm}^{3}\right)$ & $\mathrm{NO}_{2}\left(\mu \mathrm{g} / \mathrm{Nm}^{3}\right)$ \\
\hline Transportasi (Jl. Mataram) & 10 & 7 \\
Industri (Jl. Mataram) & 8 & 5 \\
Perkantoran (Balai Kota Tegal) & 5 & 4 \\
Perumukiman (Kecamatan Tegal Selatan) & 6 & 4 \\
Perdagangan (Pasar Pagi) & 7 & 5 \\
\hline
\end{tabular}

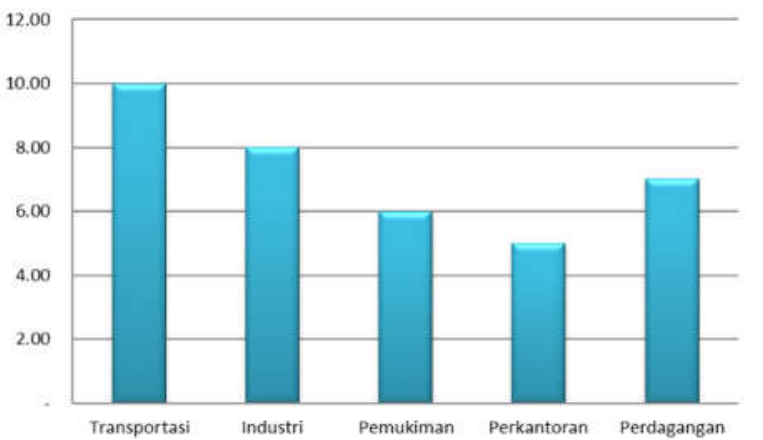

Gambar 2. Grafik Hasil Pemeriksaan Kualitas Udara Ambien di beberapa titik di Kota Tegal Parameter $\mathrm{SO}_{2}$ Tahun 2020

Berdasarkan Gambar 2, hasil pemeriksaan udara ambien di beberapa titik di Kota Tegal, terlihat bahwa konsentrasi $\mathrm{SO}_{2}$ pada udara amben yang tertinggi terukur di titik pantau kawasan transportasi Terminal Kota Tegal, sebesar $10 \mu \mathrm{g} / \mathrm{Nm}^{3}$. Sedangkan konsentrasi $\mathrm{SO}_{2}$ pada udara ambien terendah terukur di titik pantau perkantoran Balaikota Tegal sebesar $5 \mu \mathrm{g} / \mathrm{Nm}^{3}$.

Cara mencegah dampak yang dapat ditimbulkan oleh sulfur dioksida $\left(\mathrm{SO}_{2}\right)$ antara lain dengan cara :

a. sumber bergerak, dengan melakukan uji emisi secara berkala dengan merawat mesin kendaraan motor agar berfungsi dengan baik.

b. sumber tidak bergerak, dengan memasang scruber pada cerobong asap dan merawat mesin industri dengan bahan bakar yang baik.

Berdasarkan Gambar 3, pemeriksaan Kualitas Udara Ambien di beberapa titik di Kota Tegal, terlihat bahwa konsentrasi $\mathrm{NO}_{2}$ pada udara ambien yang tertinggi terukur dititik pantau kawasaan transportasi terminal Kota Tegal, sebesar $7 \mu \mathrm{g} / \mathrm{Nm}^{3}$. Sedangkan konsentrasi pada udara ambien terendah terukur di titik pantau permukiman dan perkantoran sebesar $4 \mu \mathrm{g} / \mathrm{Nm}^{3}$.

Dampak yang ditimbulkan oleh nitrogen dioksida dapat dicegah dan dikendalikan antara lain dengan mengontrol emisi kendaraan bermotor, mengontrol pusat kombusi stationer, menghindari reseptor dari daerah yang tercemar, menggunakan peralatan pengontrol gas, adsorpsi, dan konventer katalitik serta melakukan kontrol lingkungan.

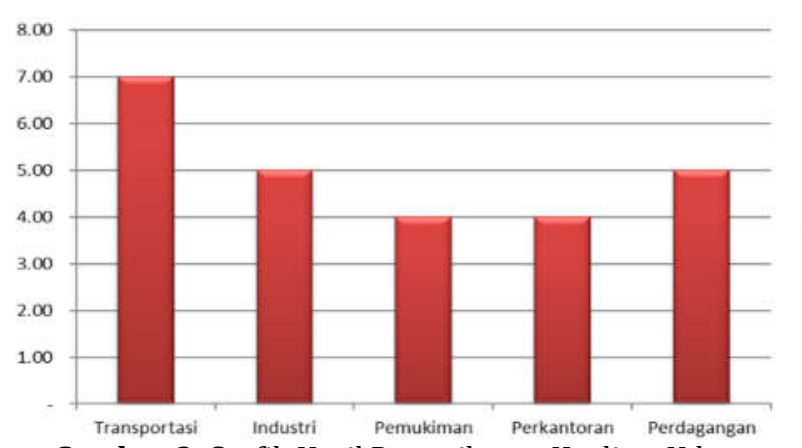

Gambar 3. Grafik Hasil Pemeriksaan Kualitas Udara Ambien di beberapa titik di Kota Tegal untuk Parameter Nitrogen Dioksida $\left(\mathrm{NO}_{2}\right)$ Tahun 2020

Hasil data kualitas udara ambien dengan metode passive sampler ini selanjutnya dapat digunakan lebih lanjut sebagai bahan kajian pengukuran pendahuluan dalam rangka mengetahui gambaran umum kualitas udara di Kota Tegal serta sebagai data dasar dalam perencanaan pengelolaan kualitas udara di Kota Tegal yang lebih komprehensif dan mendalam. Selain itu, data kualitas udara ambien tersebut juga dapat diolah untuk digunakan dalam perhitungan Indeks Kualitas Udara (IKU) Kota Tegal tiap tahunnya.

\subsection{Indeks Kualitas Udara (IKU) Kota Tegal}

Perhitungan Indeks Kualitas Udara (IKU) mengadopsi EU Directives yaitu membandingkan nilai rata-rata tahunan terhadap standar EU Directives.

Indeks Udara IKLH = $100-[50 / 0.9$ x $($ Ieu - 0.1) $]$

$\mathrm{Ieu}=$ rata rata $\left(\mathrm{SO}_{2}\right.$ hasil pemantauan dibagi $\mathrm{SO}_{2}$ Ref EU, dan $\mathrm{NO}_{2}$ hasil pemantauan dibagi $\mathrm{NO}_{2}$ Ref EU)

Tabel 9. Tabel Referensi EU untuk Kualitas Udara

\begin{tabular}{l|l}
\hline \hline Pollutant & \multicolumn{1}{c}{ Target Value / Limit Value } \\
\hline $\mathrm{NO}_{2}$ & $\begin{array}{l}\text { Year average is } 40 \mu \mathrm{g} / \mathrm{m}^{3} \\
\mathrm{PM}_{10}\end{array}$ \\
$\mathrm{PM}_{10}$ daily & $\begin{array}{l}\text { Year average is } 40 \mu \mathrm{g} / \mathrm{m}^{3} \\
\text { Number of daily averages above } 50 \mu \mathrm{g} / \mathrm{m}^{3} \text { is } 35 \\
\text { days } \\
\text { Ozone }\end{array}$ \\
$\begin{array}{l}25 \text { days with an } 8 \text {-hour average value }>=120 \\
\mathrm{PM}_{25}\end{array}$ & $\begin{array}{l}\text { Year average is } 20 \mu \mathrm{g} / \mathrm{m}^{3} \\
\mathrm{SO}_{2}\end{array}$ \\
Benzene & Year average is $20 \mu \mathrm{g} / \mathrm{m}^{3}$ \\
\end{tabular}

Sumber : Elshouf, Sef van den. (2012) 
Kriteria Indeks Udara untuk IKLH yaitu :

$\begin{array}{lll}\text { Unggul } & = & \mathrm{X}>90 \\ \text { Sangat Baik } & = & 82<\mathrm{X} \leq 90 \\ \text { Baik } & = & 74<\mathrm{X} \leq 82 \\ \text { Cukup } & = & 66 \leq \mathrm{X} \leq 74 \\ \text { Kurang } & = & 58 \leq \mathrm{X}<66 \\ \text { Sangat Kurang } & = & 50 \leq \mathrm{X}<58 \\ \text { Waspada } & = & \mathrm{X}<50\end{array}$

Sumber : IKLH Indonesia. (2019)

Dengan menghitung rata-rata dari data hasil pemantauan yang diperoleh dan selanjutnya dimasukkan dalam rumus:

Indeks Udara IKLH = $100-[50 / 0.9 \times($ Ieu -0.1$)]$, diperoleh:

Tabel 10. Data Hasil Pemantauan

\begin{tabular}{lllll}
\hline \hline No. & Lokasi & Waktu & $\mathrm{SO}_{2}$ & $\mathrm{NO}_{2}$ \\
\hline 1 & Transportasi (Jl. Mataram) & 2020 & 10,00 & 7,00 \\
2 & Industri (Jl. Mataram) & 2020 & 8,00 & 5,00 \\
3 & Perkantoran (Balai Kota Tegal) & 2020 & 6,00 & 4,00 \\
4 & Perumahan (Kecamatan Tegal Selatan) & 2020 & 5,00 & 4,00 \\
5 & Perdagangan (Pasar Pagi) & 2020 & 7,00 & 5,00 \\
& Rerata & & 7,20 & 5,00 \\
\hline
\end{tabular}

Tabel 11. Hasil Perhitungan Indeks Kualitas Udara Kota Tegal tahun 2020

\begin{tabular}{lccc}
\hline \multicolumn{1}{c}{ Parameter } & Rerata Pemantauan 2020 & Referensi EU & Index \\
\hline $\mathrm{NO}_{2}$ & 5 & 40 & 0,1250 \\
$\mathrm{SO}_{2}$ & 7,20 & 20 & 0,3600 \\
Index Udara & & & 0,2425 \\
(Index Annual model EU-Ieu) & & & 92,08 \\
Index Kualitas Udara 2020 IKLH & & & \\
\hline
\end{tabular}

Dari hasil perhitungan, diperoleh bahwa Indeks Kualitas Udara Kota Tegal untuk tahun 2020 adalah 92,08 (unggul)

\subsection{Indeks Standar Pencemaran Udara}

Indeks Standar Pencemar Udara (ISPU) diatur dalam Keputusan Menteri Negara Lingkungan Hidup Nomor 45 tahun 1997 tentang Indeks Standar Pencemaran Udara. Dampak terhadap kesehatan manusia, nilai estetika dan makhluk hidup lainnya merupakan dasar penetapan ISPU. Penetapan nilai ISPU dengan cara mengubah kadar pencemar udara yang terukur, menjadi suatu angka yang tak berdimensi yang menggambarkan kondisi kualitas udara ambien di suatu lokasi. Parameter ISPU adalah
Partikulat $\left(\mathrm{PM}_{10}\right)$; Sulfur Dioksida $\left(\mathrm{SO}_{2}\right)$; Karbon Monoksida (CO); Nitrogen Dioksida $\left(\mathrm{NO}_{2}\right)$ dan Ozon $\left(\mathrm{O}_{3}\right)$. Nilai ISPU mempunyai rentang dari 0 (baik) sampai dengan 500 (berbahaya).

Perhitungan indikator kualitas udara dilakukan berdasarkan Keputusan Kepala Bapedal No. 107 Tahun 1997 tentang Pedoman Perhitungan dan Pelaporan serta Informasi ISPU. Setiap nilai hasil pengukuran parameter-parameter tersebut dikonversikan dengan menggunakan batas indeks pencemar udara seperti pada Tabel 12 menjadi nilai ISPU dengan berpedoman pada Pengaruh hasil perhitungan ISPU ini bisa dilihat untuk setiap parameternya.

Tabel 12. Batas Indeks Pencemar Udara

\begin{tabular}{cccccc}
\hline \hline ISPU & $\mathrm{PM} 10(24 \mathrm{jam})\left(\mu \mathrm{g} / \mathrm{m}^{3}\right)$ & $\mathrm{SO}_{2}(24 \mathrm{jam})\left(\mu \mathrm{g} / \mathrm{m}^{3}\right)$ & $\mathrm{CO}(8 \mathrm{jam})\left(\mu \mathrm{g} / \mathrm{m}^{3}\right)$ & $\mathrm{O}_{3}(1 \mathrm{jam})\left(\mu \mathrm{g} / \mathrm{m}^{3}\right)$ & $\mathrm{NO}_{2}(1 \mathrm{jam})\left(\mu \mathrm{g} / \mathrm{m}^{3}\right)$ \\
\hline 50 & 50 & 80 & 5 & 120 & 282 \\
100 & 150 & 365 & 10 & 235 & 565 \\
200 & 350 & 800 & 17 & 400 & 1130 \\
300 & 420 & 21000 & 34 & 1000 & 2260 \\
400 & 500 & 2620 & 57,5 & 1200 & 3000 \\
500 & 600 & & & & 3750 \\
\hline
\end{tabular}

Sumber: Lampiran Keputusan Kepala Bapedal No 107 Tahun 1997

Parameter yang digunakan untuk menghitung ISPU berdasarkan KEP45/MENLH/10/1997 dan KEP107/KABAPEDAL/11/1997 tentang ISPU adalah partikulat berukuran $10 \mu \mathrm{m}\left(\mathrm{PM}_{10}\right)$, Sulfur Dioksida $\left(\mathrm{SO}_{2}\right)$, Karbon Monoksida (CO), oksidan dalam bentuk ozon $\left(\mathrm{O}_{3}\right)$, dan Nitrogen Dioksida $\left(\mathrm{NO}_{2}\right)$. Nilai ISPU dapat dihitung dengan pendekatan rumus sebagai berikut:

$$
I=\frac{(I a-I b)}{(X a-X b)}(X x-X b)+I b
$$

Keterangan :

I $\quad=$ ISPU tehitung

Ia $\quad=$ ISPU batas atas

$\mathrm{Ib} \quad=$ ISPU batas bawah

$\mathrm{Xa}=$ kadar ambien batas atas $(\mu \mathrm{g} / \mathrm{m} 3)$

$\mathrm{Xb}=$ kadar ambien batas bawah $(\mu \mathrm{g} / \mathrm{m} 3)$

$\mathrm{Xx} \quad=$ kadar ambien nyata hasil pengukuran $\left(\mu \mathrm{g} / \mathrm{m}^{3}\right)$ 
Tabel 13. Indeks Standar Pencemar Udara

\begin{tabular}{|c|c|c|}
\hline Kategori & Rentang & Penjelasan \\
\hline Baik & $0-50$ & $\begin{array}{l}\text { Tingkat Kualitas udara yang tidak memberikan efek bagi kesehatan manusia atau hewan } \\
\text { dan tidak berpengaruh pada tumbuhan, bangunan maupun nilai estetika. }\end{array}$ \\
\hline Sedang & $51-100$ & $\begin{array}{l}\text { Tingkat Kualitas udara yang tidak berpengaruh pada kesehatan manusia atau hewan } \\
\text { tetapi berpengaruh pada tumbuhan yang sensitif dan nilai estetika. }\end{array}$ \\
\hline Tidak Sehat & $101-199$ & $\begin{array}{l}\text { Tingkat Kualitas udara yang bersifat merugikan pada manusia ataupun kelompok hewan } \\
\text { yang sensitif atau bisa menimbulkan kerusakan pada tumbuhan dan nilai estetika }\end{array}$ \\
\hline Sangat Tidak Sehat & $200-299$ & $\begin{array}{l}\text { Tingkat Kualitas udara yang dapat merugikan kesehatan pada sejumlah segmen populasi } \\
\text { yang terpapar }\end{array}$ \\
\hline Berbahaya & 300 - lebih & $\begin{array}{l}\text { Tingkat kualitas udara berbahaya yang secara umum dapat merugikan kesehatan yang } \\
\text { serius pada populasi }\end{array}$ \\
\hline
\end{tabular}

Nilai indeks yang menggambarkan kualitas udara suatu wilayah adalah nilai maksimum dari indeks semua parameter pada semua lokasi pemantauan di wilayah tersebut. seperti contoh perhitungan dibawah ini:

\subsubsection{Indeks Standar Pencemar Udara Sulfur Dioksida ( $\left.\mathrm{SO}_{2}\right)$}

Nilai maksimum Sulfur Dioksida $\left(\mathrm{SO}_{2}\right)$ di Jl. Dr. Cipto Mangunkusumo (Terminal Kota Tegal) yaitu 34 $\mu \mathrm{g} / \mathrm{Nm}^{3}$. Dari tabel Batas Indeks Pencemar Udara diperoleh data :

$\begin{array}{ll}\mathrm{Ia} & =50 \\ \mathrm{Ib} & =0 \\ \mathrm{Xa} & =80 \mu \mathrm{g} / \mathrm{m}^{3} \\ \mathrm{Xb} & =0 \mu \mathrm{g} / \mathrm{m}^{3} \\ \mathrm{Xx} & =34 \mu \mathrm{g} / \mathrm{m}^{3}\end{array}$

$$
I=\frac{(50-0)}{(80-0)}(34-0)+0=21,25
$$

Jadi, konsentrasi udara ambien Sulfur Dioksida $\left(\mathrm{SO}_{2}\right)=34 \mu \mathrm{g} / \mathrm{m}^{3}$, diubah menjadi Indeks Standar Pencemar Udara (ISPU) adalah sebesar 21,25.

\subsubsection{Indeks Standar Pencemar Udara Carbon Monoksida (CO)}

Nilai maksimum Carbon Monoksida (CO) di Jl. Dr. Cipto Mangunkusumo (Terminal Kota Tegal) yaitu 1 $\mu \mathrm{g} / \mathrm{Nm}^{3}$. Dari tabel Batas Indeks Pencemar Udara diperoleh data :

$$
\begin{array}{ll}
\mathrm{Ia} & =50 \\
\mathrm{Ib} & =0 \\
\mathrm{Xa} & =5 \mu \mathrm{g} / \mathrm{m} 3 \\
\mathrm{Xb} & =0 \mu \mathrm{g} / \mathrm{m} 3 \\
\mathrm{Xx} & =1 \mu \mathrm{g} / \mathrm{m} 3 \\
& I=\frac{(50-0)}{(5-0)}(1-0)+0=10
\end{array}
$$

Jadi konsentrasi udara ambien Carbon Monoksida (CO) $=1 \mu \mathrm{g} / \mathrm{m}^{3}$, diubah menjadi Indeks Standar Pencemar Udara (ISPU) adalah sebesar 10.

\subsubsection{Indeks Standar Pencemar Udara Nitrogen Dioksida $\left(\mathrm{NO}_{2}\right)$}

Nilai maksimum Nitrogen Dioksida $\left(\mathrm{NO}_{2}\right)$ di Jl. Dr. Cipto Mangunkusumo (Terminal Kota Tegal) yaitu 48 $\mu \mathrm{g} / \mathrm{Nm}^{3}$. Dari tabel Batas Indeks Pencemar Udara diperoleh data :

$\mathrm{Ia}=50$

80

$$
\begin{array}{ll}
\mathrm{Ib} & =0 \\
\mathrm{Xa} & =50 \mu \mathrm{g} / \mathrm{m}^{3} \\
\mathrm{Xb} & =0 \mu \mathrm{g} / \mathrm{m}^{3} \\
\mathrm{Xx} & =48 \mu \mathrm{g} / \mathrm{m}^{3} \\
& \quad I=\frac{(50-0)}{(50-0)}(48-0)+0=48
\end{array}
$$

Jadi, konsentrasi udara ambien Nitrogen Dioksida $\left(\mathrm{NO}_{2}\right)=48 \mu \mathrm{g} / \mathrm{m}^{3}$, diubah menjadi Indeks Standar Pencemar Udara (ISPU) adalah sebesar 48.

\subsubsection{Indeks Standar Pencemar Udara Ozon $\left(\mathrm{O}_{3}\right)$}

Nilai maksimum Ozon $\left(\mathrm{O}_{3}\right)$ di Jl. Dr. Cipto Mangunkusumo (Terminal Kota Tegal) yaitu 55 $\mu \mathrm{g} / \mathrm{Nm}^{3}$. Dari tabel Batas Indeks Pencemar Udara diperoleh data:

$$
\begin{array}{ll}
\mathrm{Ia} & =50 \\
\mathrm{Ib} & =0 \\
\mathrm{Xa} & =120 \mu \mathrm{g} / \mathrm{m}^{3} \\
\mathrm{Xb} & =0 \mu \mathrm{g} / \mathrm{m}^{3} \\
\mathrm{Xx} & =55 \mu \mathrm{g} / \mathrm{m}^{3}
\end{array}
$$

$$
I=\frac{(50-0)}{(120-0)}(55-0)+0=22,92
$$

Jadi konsentrasi udara ambien Ozon $\left(\mathrm{O}_{3}\right)=55$ $\mu \mathrm{g} / \mathrm{m}^{3}$, diubah menjadi Indeks Standar Pencemar Udara (ISPU) adalah sebesar 22,92.

\subsubsection{Indeks Standar Pencemar Udara Partikulat (PM10)}

Nilai maksimum Partikulat $\left(\mathrm{PM}_{10}\right)$ di Jl. Dr. Cipto Mangunkusumo (Terminal Kota Tegal) yaitu 40 $\mu \mathrm{g} / \mathrm{Nm}^{3}$. Dari tabel Batas Indeks Pencemar Udara diperoleh data :

$$
\begin{array}{ll}
\mathrm{Ia} & =50 \\
\mathrm{Ib} & =0 \\
\mathrm{Xa} & =50 \mu \mathrm{g} / \mathrm{m}^{3} \\
\mathrm{Xb} & =0 \mu \mathrm{g} / \mathrm{m}^{3} \\
\mathrm{Xx} & =40 \mu \mathrm{g} / \mathrm{m}^{3} \\
& I=\frac{(50-0)}{(50-0)}(40-0)+0=40
\end{array}
$$

Jadi konsentrasi udara ambien Partikulat $\left(\mathrm{PM}_{10}\right)=$ $40 \mu \mathrm{g} / \mathrm{m}^{3}$, diubah menjadi Indeks Standar Pencemar Udara (ISPU) adalah sebesar 40. Nilai ISPU Kota Tegal tahun 2020 dapat dilihat pada Tabel 14. 
Tabel 14. Nilai Indeks Standar Pencemar Udara Kota Tegal Tahun 2020

\begin{tabular}{lcll}
\hline \hline Parameter & Nilai Maksimum $\left(\mu \mathrm{g} / \mathrm{Nm}^{3}\right)$ & Nilai ISPU & Kategori \\
\hline Sulfur Dioksida $\left(\mathrm{SO}_{2}\right)$ & 34 & 21,25 & Baik \\
Carbon Monoksida $(\mathrm{CO})$ & 1 & 10,00 & Baik \\
Nitrogen Dioksida $\left(\mathrm{NO}_{2}\right)$ & 48 & 48,00 & Baik \\
Ozon $\left(\mathrm{O}_{3}\right)$ & 55 & 22,92 & Baik \\
Partikulat $\left(\mathrm{PM}_{10}\right)$ & 40 & 40,00 & Baik \\
\hline
\end{tabular}

Nilai Indeks Standar Pencemar Udara (ISPU) pada lokasi pemantauan di Jl. Dr. Cipto Mangunkusumo (Terminal Kota Tegal) pada seluruh parameter termasuk dalam rentang 0 - 50 dengan kategori baik.

\section{Kesimpulan}

Secara umum, kualitas udara ambien pada lokasi terpilih masih memenuhi baku mutu yang dipersyaratkan, namun parameter sufida dan kebisingan memiliki nilai yang berada di atas baku mutu, yaitu di Jl. Dr. Cipto Mangunkusumo (Depan Terminal Kota Tegal). Nilai Indeks Standar Pencemar Udara (ISPU) pada lokasi pemantauan di Jl. Dr. Cipto Mangunkusumo (Terminal Kota Tegal) pada seluruh parameter termasuk dalam rentang 0 - 50 dengan kategori baik. Indeks Kualitas Udara Kota Tegal untuk tahun 2020 adalah 92,08 (unggul).

\section{Saran}

Untuk mengatasi masalah kebisingan, maka perlu kiranya dilakukan kerjasama antara pemerintah Kota Tegal dan masyarakat dalam menjaga kondisi kendaraan bermotor. Dengan terpeliharanya mesin serta kondisi kendaraan yang baik, misalnya dengan memasang filter pada knalpot kendaraan, maka diharapkan suara bising kendaraan bermotor akan berkurang, dan secara umum tingkat kebisingan di titik-titik pantau Kota Tegal akan berkurang dan diharapkan akan memenuhi baku mutu yang ditetapkan.

Untuk mengatasi masalah tingginya kadar partikulat di udara dapat dilakukan penghijauan di area wilayah yang kering dan tandus serta area industri. Selain dapat membersihkan udara dari polutan berbahaya, tanaman juga dapat menahan hempasan angin yang terlalu kencang yang menyapu debu jalanan ke udara. Pohon-pohon yang dapat ditanam diantaranya jenis pohon Angsana, Akasia, Waru, Bambu Cina dll.

Dilakukannya monitoring dan sosialisasi berkelanjutan oleh pemerintah setempat khususnya oeh Dinas Lingkungan Hidup (DLH) sebagai leading sector bagi pengelolaan lingkungan hidup di Kota Tegal dalam rangka terciptanya tujuan program langit biru guna mendorong peran serta masyarakat dan seluruh stakeholder dalam pengelolaan kualitas udara di Kota Tegal. Salah satunya dengan memberikan edukasi terhadap industri dan masyarakat untuk mengurangi penggunaan bahan bakar minyak bumi agar limbah udara yang terlepas ke atmosfer dapat berkurang. Disamping itu perlu adanya sosialisasi akan penerapan energi alternatif yang lebih ramah lingkungan seperti penggunaan biogas, energi surya atau energi panas bumi.
Pengendalian pencemaran udara yang disebabkan oleh kegiatan masyarakat dapat dilakukan melalui sosialisasi dan pembinaan kepada masyarakat tentang pentingnya pengelolaan dan pemilahan sampah yang baik, tanpa harus membakar sampah di udara terbuka. Dengan demikian diharapkan akan terwujudnya peningkatan partisipasi masyarakat dalam hal mewujudkan udara yang bersih di wilayah Kota Tegal.

\section{DAFTAR PUSTAKA}

Agustini T, Gunawan A, Imamkhasari S. 2010. Pembuatan Sampling Gas Dalam Udara Ambient. Jakarta (ID): Penerbit Warta Kimia Analitik.

Aisyiah Km Latra I . 2014. Pemodelan Konsentrasi Partikel Debu (PM10) pada Pencemaran Udara di Kota Surabaya dengan Metode Geographically-Temporally Weighted Regression. J Sains dan Seni Pomits. Vol. 2 No. 1.

Akmal .2009. Dampak Gas CO Terhadap Kesehatan. http://vhatal.(akmal): Dampak Gas Co Terhadap Kesehatan.htm (diakses 20 September 2020).

Anonim (2013). Pencemaran Suara. (Online): (http://pollutiononmyearth.weebly.com/6/1756520 9/4266920_orig.jpg. (Diakses 15 September 2020).

Arya Wardana, Wisnu. 2001. Dampak Pencemaran Lingkungan. Yogyakarta. Penerbit Andi.

Bachla D, Mc Lahlan W. 1992. Applited Electronic Instrumentation andMeasurement. New Jersey (US) : Pretice Hall.

Badan Pengendalian Dampak Lingkungan (Bapedal). 1997. Keputusan Kepala Bapedal KEP107/KABAPEDAL/11/1997. Jakarta.

Fauziah D.A , Rahardjo M, Dewanti N.A.Y. 2017. Analisis Tingkat Pencemaran Udara di Terminal Kota Semarang. Jurnal Kesehatan Masyarakat Vol.5, No.5. Universitas Diponegoro Semarang.

Hadi A. 2005. Prinsip Pengambilan Sampel Lingkungan. Bogor (ID) : Grafika Mahdi Yuana.

Kementrian Lingkungan Hidup dan Kehutanan. 2016. Pemantauan Kualitas Udara Ambien dengan Metode Passive Sampler.

Keputusan Gubernur Provinsi Jawa Tengah No. 8 Tahun 2001, tentang "Baku Mutu Ambien Untuk Provinsi Jawa Tengah".

Keputusan Menteri Lingkungan Hidup No. 48 Tahun 1996 tentang Baku Tingkat KeBisingan.

Keputusan Menteri Negara Lingkungan Hidup No. : KEP50/MENLH/11/1996 Tentang Baku Tingkat Kebauan.

Kota Tegal Dalam Angka 2020. BPS Kota Tegal.

Kusnoputranto, H, Susana, D. 2000. Kesehatan Lingkungan. Depok : Fakultas Kesehatan Masyarakat Universitas Indonesia.

Lakitan B. 1994. Dasar-dasar Klimatologi. Jakarta (ID) : Raja Grafindo Persada.

Li L, Moore PK. Putative Biological Roles of Hydrogen Sulfide in Health and Desease: A Breath of Not So Fresh Air?. 
Trends in Pharmacological Sciences Vol. 29 No. 2. Pages 84-90. 2008.

Menteri Negara Lingkungan Hidup. 1997. Keputusan Menteri Negara Lingkungan Hidup No.45/MENLH/10/1997 Tentang: Indeks Standar Pencemar Udara.

Mulia, R.M. 2005. Kesehatan Lingkungan. Yogyakarta: Graha Ilmu.

Nugroho, N. 2008. Pencemaran Udara. Yogyakarta: Poltekkes Depkes Jurusan Kesehatan Lingkungan.

Nurmaningsih D.R. 2018. Analisis Kualitas Udara Ambien Akibat Lalu Lintas Kendaraan Bermotor di Kawasan Coyudan, Surakarta. Jurnal Teknik Lingkungan Vol. 3 No. 2. Hal. 46-53.

Peratuan Pemerintah Republik Indonesia No. 41 Tahun 1999 tentang "Pengendaliaan Pencemaran Udara".
Peraturan Daerah Kota Tegal Nomor 2 Tahun 2016 tentang Perlindungan dan Pengelolaan Lingkungan Hidup.

Peraturan Daerah Provinsi Jawa Tengah Nomor 5 Tahun 2007 tentang Pengendalian Lingkungan Hidup Tingkat Provinsi Jawa Tengah.

Perda Kota Tegal No 4 tahun 2012 Rencana Tata Ruang Wilayah (RTRW) Kota Tegal tahun 2011-2031.

Reiffenstein RJ, Hulbert WC, Roth SH. 1992. Toxicology of Hydrogen Sulfide. Pharmacology and Toxicology Journal Vol. 32. Pages 109-134.

SNI 19-7119.1-2005 tentang Udara Ambien - Bagian 1: Cara Uji Kadar Amoniak (NH3) dengan Metoda Indofenol Menggunakan Spektrofotometer

Srikandi Fardiaz, 1992, Polusi Air dan Udara. Penerbit Kanisius. Yogyakarta. 